Tijdschrift Voor Verzorgenden (TVV) is het vakblad voor verzorgenden IG, verzorgenden en helpenden, werkzaam in verpleeghuizen, verzorgingshuizen, thuiszorg, gehandicaptenzorg en kraamzorg.

TVV wordt vitgegeven onder auspiciën van de Stichting Publikaties voor Verpleegkundigen en Verzorgenden (SPVV) en is een uitgave van Bohn Stafleu van Loghum, onderdeel van Springer Nature

\section{Redactie TvV}

Rhiija Jansen, hoofdredacteur

Gerben Stolk, eindredacteur

Uitgever

Yolanda Stil

\section{Redactieraad}

Joyce Bleeker, Sandra Fortuin, Julian Hooikaas, Esther Kerkhoven, Sietske Posthuma en Marieke Püttmann

\section{Redactiesecretariaat TvV}

BSL, t.a.v. TVV, Postbus 246, 3990 GA Houten,

tel. 030 - 63838 43, redactie.tvv@bsl.nl

\section{Abonnementen}

Wil je ook een abonnement? Ga naar www.bsl.nl/shop, zoek op "Tiidschrift Voor Verzorgenden". TVV verschijnt 6 keer per jaar. Abonnementspri|zen: per jaar, incl. btw: TVV (printmagazine + digitaal magazine + online archief) $€ 75,00$ / studenten $€ 37,50$. Los nummer: $€ 13,00$. Het abonnement kan elk gewenst moment ingaan en wordt automatisch verlengd tenzii twee maanden voor de vervaldatum is opgezegd via het daarvoor bestemde formulier op www.bsl.nl/klantenservice. Als vakblad hanteren wij de opzegregels uit het verbintenissenrecht. We gaan er vanuit dat je het abonnement vit hoofde van jouw beroep hebt afgesloten. Abonnementenadministratie: Klantenservice Bohn Stafleu van Loghum, Postbus 246, 3990 GA Houten. Telefoon: 030-638 3736 Bij wijziging van de tenaamstelling en/of adres verzoeken wij je de adresdrager met de gewijzigde gegevens op te sturen naar afdeling klantenservice of wijzigingen door te geven via het formulier op www.bsl.nl/klantenservice.

\section{Advertenties}

Cross Media Nederland 010 - 7421020 ,

zorg@crossmedianederland.com

Aanleveren advertentiemateriaal, 030 - 638 36,03, traffic@bsl.nl

Voorwaarden

Op leveringen en diensten zijn de bij de Kamer van Koophandel gedeponeerde algemene voorwaarden van Springer Media B.V. van toepassing, tevens raadpleegbaar op www.bsl.nl. De voorwaarden worden op verzoek toegezonden. Het overnemen en vermenigvuldigen van artikelen en berichten uit dit tijdschrift is slechts geoorloofd met bronvermelding en met schriftelijke toestemming van de vitgever. Het verlenen van toestemming tot publicatie in deze vitgave houdt in dat de Standaardpublicatievoorwaarden van Springer Media B.V., gedeponeerd bij de Kamer van Koophandel te Utrecht onder dossier nummer 3210/635, van toepassing zijn, tenzii schriftelijk anders is overeengekomen. De Standaard publicatievoorwaurden voor tiidschriften zijn in te zien op www.bsl.nl/ schrijven-bij-bohnstafleu-van-loghum/auteursinstructies of kunnen bii de vitgever worden opgevraagd. www.bsl.nl

(C) 2020, Bohn Stafleu van Loghum ISSN 0921-5832
"IK WILDE ERVOORMISN

CLIËNTEN ZIUN IN DEZE

RARE TISD'

\title{
WEER EEN WARM WELKOM
}

2020 is nog volop aan de gang, maar het is nu al een jaar om nooit meer te vergeten. Door het coronavirus is de hele wereld, inclusief Nederland, in rep en roer. Het dagelijkse leven zag er opeens heel anders vit.

Mijn werk in de thuiszorg heb ik als heel bijzonder ervaren. Vooral in de beginperiode was er veel onwetendheid en onduidelijkheid over de richtlijnen in de thuiszorg. Het ontbrak aan persoonliike beschermingsmiddelen. Natuurlijk wilde ik er voor mijn cliënten zijn in deze rare tijd, maar onbeschermd werken gaf toch een vervelend gevoel. Ik was bang dat ik een cliënt zou besmetten of dat ikzelf besmet zou worden. Elk kuchie, elk hoestje en elke verhoging kwam onder een vergrootglas te liggen; het waren toch geen symptomen van corona?

Een paar maanden lang heb ik standaard gewerkt met handschoenen aan en een mondkapje op. Het is niet prettig om zo aan de slag te zijn, maar voor ieders veiligheid wel van groot belang.

Cliënten hebben vaak hun waardering en dankbaarheid uitgesproken in deze periode. Ze dachten echt niet alleen aan hun eigen gezondheid, maar ook aan die van mijn collega's en mij. Geregeld ben ik thuisgekomen met een presentje als dank voor de goede zorgen. Sommige cliënten of hun familieleden kozen ervoor de thuiszorg tijdelijk te stoppen, vit angst voor besmetting.

In deze tijd ontstonden ook mooie momenten: de dochter van een 91 -jarige cliënt besloot tijdelijk bij haar vader met dementie in te gaan wonen om zo voor hem te kunnen zorgen. Zowel dochter als vader heeft hier erg van genoten. Toen mijn zorgcoördinator de cliënt belde om te vragen hoe het met hem ging, gaf hij als antwoord: 'Goed! Ik heb het gevoel dat ik samen met mijn dochter op vakantie ben.' Dit antwoord ontroerde me echt.

Op dit moment zijn bijna alle cliënten terug in zorg. Soms hebben we elkaar drie maanden niet gezien en krijg ik wederom een warme en hartelijke ontvangst. Dit zijn de kleine dingen die het werken in de thuiszorg voor mij zo bijzonder maken.

Sandra Fortuin werkt als verzorgende ig bij Bonniers Thuiszorg

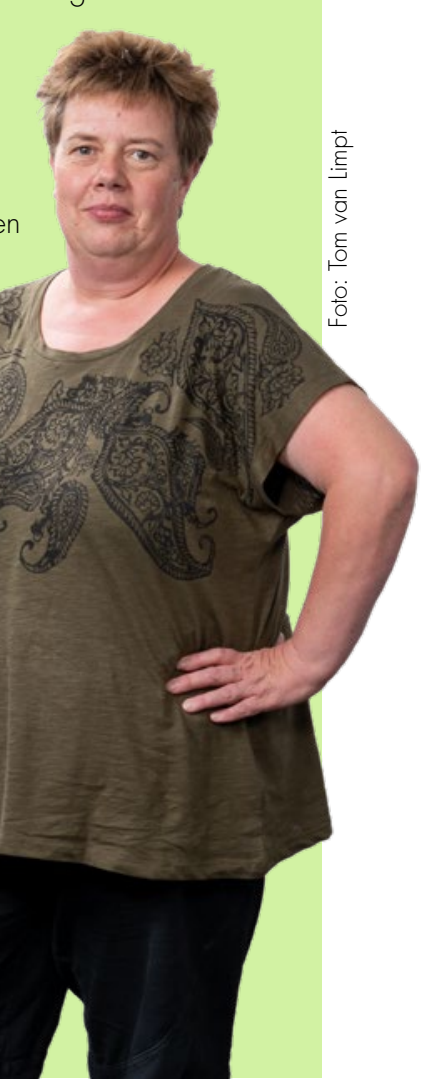




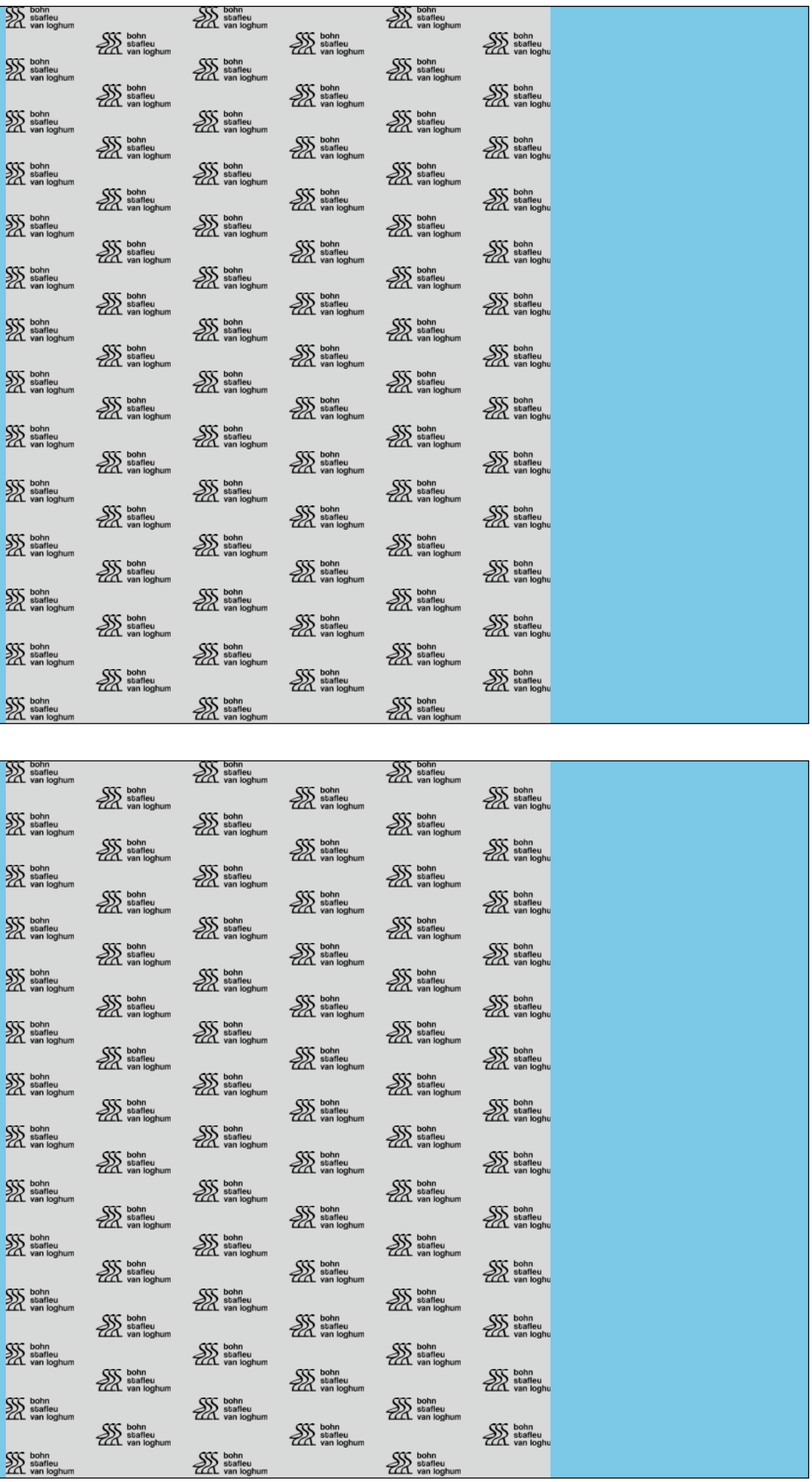

